\title{
Comparing Mediation Effect of Functional and Emotional Value in the Relationship between Pros of Applying Big Data Analytics and Consumers' Responses
}

\author{
Shu-Yi Liaw ${ }^{1} \&$ Thi Mai Le ${ }^{2}$ \\ ${ }^{1}$ Management College, Computer Centre, National Pingtung University of Science and Technology, Taiwan \\ ${ }^{2}$ Department of Tropical Agriculture and International Cooperation, National Pingtung University of Science \\ and Technology, Taiwan \\ Correspondence: Thi Mai Le, Department of Tropical Agriculture and International Cooperation, National \\ Pingtung University of Science and Technology, Taiwan. E-mail: lemai.istnu@gmail.com
}

Received: May 26, 2017 Accepted: June 17, $2017 \quad$ Online Published: July 28, 2017

doi:10.5539/ijms.v9n4p66 URL: http://doi.org/10.5539/ijms.v9n4p66

\begin{abstract}
Applying Big Data analytics application brings many benefits for e-vendors and customers. Exploring the effect of consumer perceived value to consumers' responses under applying Big Data analytics is lacking. And, what kind of perceived values do customers have more concerns under Big Data era. Therefore, the aims of this study are to analyze relationship between pros of applying Big Data analytics and Consumers' responses under multiple mediators of perceived values as functional value and emotional value. Data analysis was done in a sample of 349 respondents. The results show that applying Big Data analytics have significant positive effect on customers' responses. Functional and emotional values act as important mediators on the relationship between applying Big Data analytics and consumers' responses. There are no significant different between mediator effect of functional value and emotional value. The findings of this study will have implications for e-vendors to understand the important mediator of perceived value on customers' responses under Big Data analytics era.
\end{abstract}

Keywords: e-commerce, Big Data analytics, functional value, emotional value, customers' responses

\section{Introduction}

The amount of data is increasing faster than before due to the continuous generation of the data from many organizations' sources. Therefore, applying the applications of Big Data analytics (BDA) become a trend in all others industries such as healthcare, government, insurance, manufacturing and natural resources and others. Specially, in the e-commerce context, BDA can enable to track customers' behavior and determine the most effective way to connect with new customers and keep the repeat customers (Akter \& Wamba, 2016). Applying BDA contributes the higher performance business by providing for e-vendors with transformative benefits to their customers, like as information search, recommendation system, dynamic pricing and customer services (Le \& Liaw, 2017). The e-commerce firms that apply BDA into their value chain 5-6\% higher efficiency comparing with their competitors (McAfee, Brynjolfsson, Davenport, Patil, \& Barton, 2012). Because of the high benefits of applying BDA in e-commerce to business value and satisfying their customers, BDA has become the trend for recent academic research and industry exploration. Applying BDA in e-commerce can offer many benefits for customers via website such as information search, recommendation system, dynamics pricing and improved customer services.

However, the problem that customers think about the application of applying BDA in running online shopping of e-vendors is not evaluated. Besides, when customers take online shopping, they may want to find benefits for them, like functional value as ease-of-use and satisfactory outcome and emotional values which provide enjoyment of shopping (Bridges \& Florsheim, 2008). Cowles, Kiecker, \& Little (2002) stated that e-commerce research should consider which kind of perceived value behind customers as their motivation to online shopping.

With those motivations, this research aims to evaluate the mediation effects of functional and emotional value on relationship between positive factor of applying BDA and customers' responses. Another purpose of this study is to examine which mediating effect of functional and emotional value has stronger effect. This contribution of this 
study could answer the question that is it worth for e-vendors to apply the new tool (BDA) and what kind of perceived value that customers are more interested under Big Data era.

\section{Literature Review and Research Hypotheses}

\subsection{Customers' Responses}

A positive consumers' response is a vital intangible asset for an organization and help to grow substantially business either in direct or indirect way. From literature review, there are many ways to measure the customers' responses. However, the AIDA construct (A-Attention, I-Interest, D-Desire, A-Action) is famous presented model for measuring the effective of advertising and marketing on customers responses (Gharibi, Danesh, \& Shahrodi, 2012). Under applying application of Big Data analytics, e-vendors will be successful if they can lead their customers to through four stages of hierarchical model as AIDA. Stage one is attracting customers to their new application by applying BDA. Stage two is generating customers' interest and demonstrating features and benefits, consumers get interested in their products or services. Stage three is create customers' desire that make customers feel it is worth to get the products or use the services. After three stages leads to stage four, customers take action to want to know about purchasing and to take the final decision to end the process. The AIDA model was developed in the 1920s based on theory of attracting attention, getting interest, motivating desire, and precipitating action (Mackay, 2005). Moreover, the AIDA model was applied to measured customers' resonponse in others studies (Ehrenberg, 2000; Lee, Lin, Liao, \& Yeh, 2013).

\subsection{The Relationship between Positive Factor of Applying BDA and Customers' Responses}

Big Data analytics is defined as a process that includes collection, analysis, and interpretation of Big Data to gain insight value, create business value and establish the competitive advantages (Akter \& Wamba, 2016). Applying BDA bring advantages for e-vendors to use their data in effective way, improve their decision making and empower their customers. Specially, firms apply BDA to track their customers' behavior, determine the customers' updated trend to gain new customers and keep repeat customers. From customers' view, applying BDA can offer many positive factors for customers. Positive factors of applying BDA concludes providing information search, recommendation system, dynamic pricing and customer services (Le \& Liaw, 2017).

By using BDA, e-vendors can record and filter from large information to information which customers need. This application enables to provide the right products to right person at right time. The information search is achived by applying BDA which are quicky responeses (Delone \& McLean, 2003), suitable, realistic and real-time services. Recommendation system is the most important application of applying BDA to design the website. It is now offererd in Amazon, eBay, Taobao and other many famous websites. By using different algorithms in BDA as collabrorative filtering (Huang, Zeng, \& Chen, 2007) to evaluate the products, customers' interest and recommend for customers alternate or complementary products. Recommendation system also refer the best-selling products or the hottest commodity information to recommend and push these information to customers. This recommendation action could enhance customers' interest on website, provide consumers more choice and satisfy customers' need. The purpose of dynamic pricing is to provide different prices for different customer, location, product ad time (Kotler \& Armstrong, 2000). Based on Big Data of customers' information like as demographics, geographic distribution, customers behavior, firms enable to adjust price of product and offer for individual customers. Therefore, the dynamic pricing has been made more flexibility strategy to satisfy online customers (Haws \& Bearden, 2006). Besides, the above applications, using BDA also enhance business process by offering the track customers' order, virtual product experiences, buyer community to review customer's feedback. These services can inspire customers with positive behavior with e-vendors' website. All these applications of BDA will help to catch customers' attention, gain customers' interest, enhance desire and lead them to take action to purchase. Therefore, the hypothesis is as following:

Hypothesis $\left(\mathbf{H}_{\mathbf{1}}\right)$ : The positive factor has positive relation with customers' responses.

\subsection{The Mediating Role of Functional Value and Emotional Value}

Perceived value has been become the most important concept of marketing practice in recent years (Aulia, Sukati, \& Sulaiman, 2016) and succesful key for all companies (Huber, Herrmann, \& Morgan, 2001). Perceived value's dimensions and their effects to customers' responses were stated in previous studies (Aulia et al., 2016; Carlos Fandos Roig, Sanchez Garcia, Angel Moliner Tena, \& Llorens Monzonis, 2006; Sanchez, Callarisa, Rodriguez, \& Moliner, 2006). Perceived value should not only viewed from ultitarian value which based on products' performance or functions, but also it should be based on the feelings of customers after experiencing (Holbrook \& Hirschman, 1982). Therefore, functional and emotional value are the most two important dimensions of perceived value. Perceived value was found to be a powerful predictor of purchase intention (Zeithaml, 1988), as well as 
moderator (Chen, 2012). Howerver, perceived value's dimesions play the mediating role in the positive factor of applying BDA-customers' responses relation need to be examined.

Functional value is defined as an overall assessment of functional benefits (i.e., considering the product, service, ad price features) (Overby \& Lee, 2006). Within the functional dimension of value they include the fators like quality and price (customers can buy the needed product with acceptable price and quality) (Carlos Fandos Roig et al., 2006) and versatility of website (easy to use and informative). Functional benefits include cost-saving, convenience, selection, information availability, customized product or service influence. With four application of applying BDA as mention above, information search can offer information available with needed information, recommendation system offer different choices for customers to customize products, dynamic pricing enables customers to save cost and customers services are enhanced. Therefore, positive factor of applying BDA will affect to functional value, and functional value can enhance positive customers' responses. Therefore, we propose the hypothesis as following:

Hypothesis $\left(\mathbf{H}_{2}\right)$ : Functional value mediates the relationship between positive factor of applying BDA and customers' response.

Emotional value mentioned of the feelings or the affective states generated by the customers' experiences (Carlos Fandos Roig et al., 2006). Sanchez et al. (2006) researched that emotional value component related to internal emotions or feelings. The value of shopping activity can also be seen from the view how pleasure customers received. From this view, consumers often consider the feeling in using services is also their basic need and have begun to be recognized as more important dimension of online shopping (Overby \& Lee, 2006). Therefore, experiences such as joyful or relax from the website will also influence the customers' responses. Using BDA application in the website, the customers may receive different joys which are offered by recommendation system, customers' services.

Hypothesis $\left(\mathbf{H}_{3}\right)$ : Emotional value mediates the relationship between positive factor of applying BDA and customers' response.

There are many arguments that the stronger effect of functional value and emotional value. Sweeney and Soutar (2001) stated that emotional value has greater effect than the functional value. Another study reported that functional value is likely play a stronger role than emotional value in the information forwards to the online shopping (Teo, 2001). It also has another finding stated that both functional value and emotional value are important aspects to customers' behavior (Lim, Widdows, \& Park, 2006). Therefore, the following hypothesis is realized to examine:

Hypothesis $\left(\mathbf{H}_{4}\right)$ : Functional value plays a stronger mediating role than emotional value in the relationship between positive factor of applying BDA and customers' response.

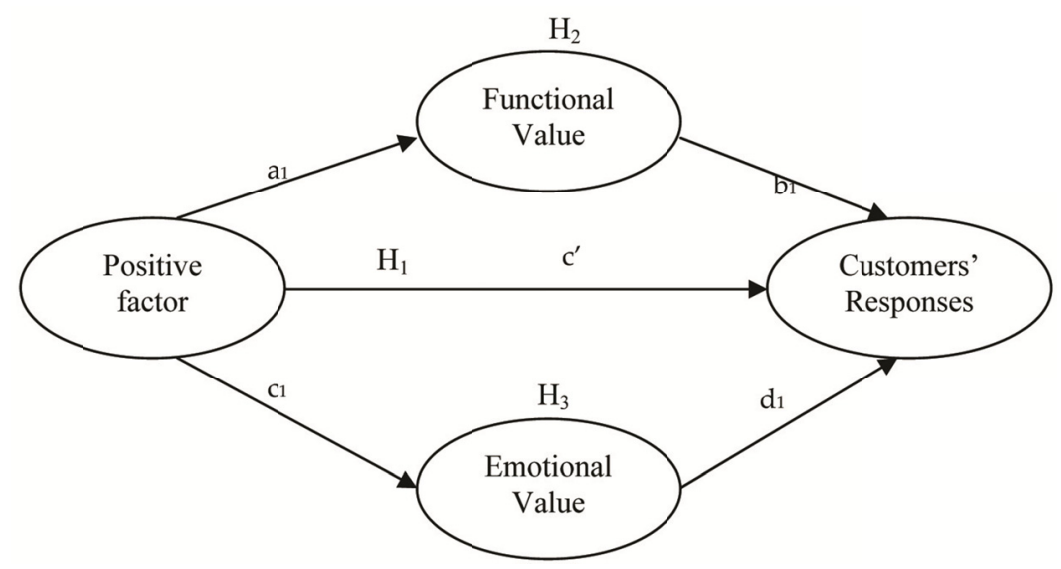

Figure 1. The research model 


\section{Research Methodology}

\subsection{Sample Selection}

Data comes from survey after respondent interacted with Amazon website (www.amazon.com) which a famous website using application of Big Data analytics. The respondents need to take an action through until the ending the process of purchasing one kind of products on the website, but not actually purchase to that item. Students were invited to participate in this study because college students have many experiences in using the Internet. The using college students as sample have been stated in many previous studies (Gefen, 2002; Kuo, Wu, \& Deng, 2009). In addition, students nowadays are the key convenient shopper and become potential customers of e-commerce market.

A sample size of 372 students from Thai Nguyen University, Vietnam participated in this study during in 2016 and 2017. About 23 questionnaires were not fully completed and were removed before analysis. The rest of 349 samples were used for analysis. The majority $(62.2 \%)$ of respondents are female. The customers had interaction with one of two kinds of products are similar percentage: fashion item (50.4\%), electronics item $(49.6 \%)$. The largest $(31.2 \%)$ of respondents have experiences each month $1-2$ times on website and $18.9 \%$ respondents have no experiences with online shopping.

\subsection{Measurement}

Measurement variables were shown in table 1 which is considered for each construct used in this research. The measurement variables were used in this research according to related literature. A total 4 constructs were used. First, positive factors of applying Big Data analytics was measured on four variables and adopted from previous study (Le \& Liaw, 2017; Tang \& Wu, 2015). Second, two validated items were to measured functional value taken from the studies (Carlos Fandos Roig et al., 2006; Sanchez et al., 2006). Third, emotional value was measured on two items based on previous studies (Carlos Fandos Roig et al., 2006; Sanchez et al., 2006). Fourth, customers' response was measure by AIDA model in four variables based on (Ehrenberg, 2000; Lee et al., 2013). The questionnaire includes two sections. The main section measures the respondents' perception of each construct in research model under using a seven-point Likert scale ranging from 1 (strongly disagree) to 7 (strongly agree). In another section, several demographic characteristics were assessed: gender, experiences and which product was chosen to interact with website. The research construction and items included in the questionnaire are presented in Table 1.

Table 1. Constructs and items included in the questionnaire

\begin{tabular}{|c|c|c|c|}
\hline Constructs & Variables & Items & Measurements \\
\hline \multirow{16}{*}{ Positive factor } & \multirow{4}{*}{$\begin{array}{l}\text { Information Search } \\
\text { (IS) }\end{array}$} & IS1 & I am able to search the useful information in the e-shopping website \\
\hline & & IS2 & $\begin{array}{l}\text { The information I search in the e-shopping site are detailed and } \\
\text { completed }\end{array}$ \\
\hline & & IS3 & The result is provided quickly and fit to my need \\
\hline & & IS4 & Search result provided by shopping website is very realistic. \\
\hline & \multirow[t]{4}{*}{$\begin{array}{l}\text { Recommendation System } \\
\text { (RS) }\end{array}$} & RS1 & $\begin{array}{l}\text { Shopping website can recommend substitute goods for the product I } \\
\text { want to buy. }\end{array}$ \\
\hline & & RS2 & $\begin{array}{l}\text { Shopping website can recommend complementary goods for the } \\
\text { product I want to buy. }\end{array}$ \\
\hline & & RS3 & $\begin{array}{l}\text { Shopping website can recommend for you some product may be you } \\
\text { like or best sellers of website }\end{array}$ \\
\hline & & RS4 & I believe that the recommendation information is an act of kindness. \\
\hline & \multirow[t]{4}{*}{ Dynamic Pricing (PD) } & PD1 & Providing different prices for individual customer at the same time \\
\hline & & PD2 & Offer different prices at different time \\
\hline & & PD3 & Providing different prices with different substitute products \\
\hline & & PD4 & Providing different prices with different conditions on the same product \\
\hline & \multirow[t]{4}{*}{ Customer Services (CS) } & CS1 & The website provides channel to support customers \\
\hline & & $\mathrm{CS} 2$ & I expect that I am able to track my order \\
\hline & & $\mathrm{CS} 3$ & $\begin{array}{l}\text { The shopping website which provides virtual experience can let me } \\
\text { choose more suitable goods. }\end{array}$ \\
\hline & & $\mathrm{CS} 4$ & I can refer to the reviews of customers who bought the products before \\
\hline \multirow[t]{2}{*}{ Functional Value (FV) } & Functional Value 1 & FV1 & $\begin{array}{l}\text { Information obtained from e-vendor website are easy to understand and } \\
\text { useful }\end{array}$ \\
\hline & Functional Value 2 & FV2 & $\begin{array}{l}\text { I can buy product with acceptable quality and price which I want from } \\
\text { shopping website }\end{array}$ \\
\hline \multirow[t]{2}{*}{ Emotional Value (EV) } & Emotional Value 1 & EV1 & When using the shopping website, I feel relaxed and enjoy my time \\
\hline & Emotional Value 2 & EV2 & I feel I can save time for shopping \\
\hline
\end{tabular}




\begin{tabular}{|c|c|c|c|}
\hline \multirow[t]{4}{*}{$\begin{array}{l}\text { Customer Responses } \\
\text { (CR) }\end{array}$} & Customer Attention & $\begin{array}{l}\text { CAT1 } \\
\text { CAT2 } \\
\end{array}$ & $\begin{array}{l}\text { The applications on website catches my attention } \\
\text { I had trying to read that information }\end{array}$ \\
\hline & Customer Interest & $\begin{array}{l}\text { CI1 } \\
\text { CI2 } \\
\end{array}$ & $\begin{array}{l}\text { Continuously pay attention } \\
\text { I want to get more information }\end{array}$ \\
\hline & Customer Desire & $\begin{array}{l}\mathrm{CD} 1 \\
\mathrm{CD} 2 \\
\end{array}$ & $\begin{array}{l}\text { I want to buy the product } \\
\text { I will continue to use this webpage for shopping. }\end{array}$ \\
\hline & Customer Action & $\begin{array}{l}\mathrm{CAC} 1 \\
\mathrm{CAC} 2\end{array}$ & $\begin{array}{l}\text { I will have action to buy } \\
\text { I will introduce this webpage to my friends and family. }\end{array}$ \\
\hline
\end{tabular}

\subsection{Statistical Data Analyses}

To analyze data, the statistical package for social sciences (SPSS 22.0) and analysis of moment structures (AMOS 22.0) software were used. SPSS 22.0 was used to test the reliability of measurement items and descriptive analysis. Confirmatory factor analysis (CFA) was used to measure for the reliability, convergent and divergent validity, followed by using SEM to test hypothesized relationships in AMOS 22.0. The Sobel z Test was used to calculate the indirect effect of mediation model. According to Preacher \& Hayes (2008) the Sobel Test which also called the product-of-coefficients approach to calculate the ratio of path coefficient of mediation path to its estimated standard error (SE).

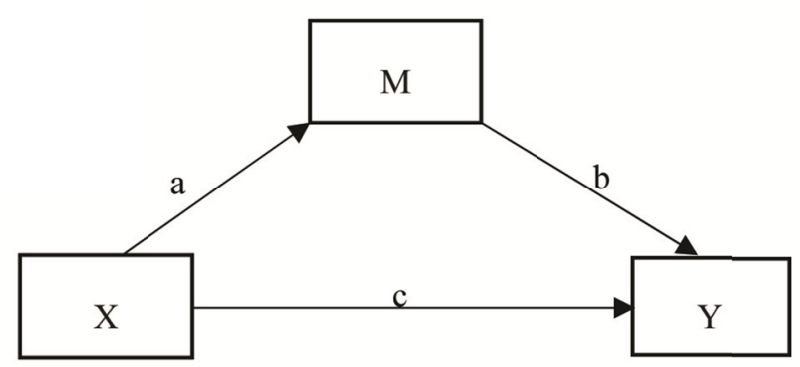

Sobel has produced an appropriate significance test for the indirect effect of the independent variable on the dependent variable through the mediator. The path from the independent variable (X) to the mediator (M) is denoted as $a$ and its standard error is $s e_{a}$; the path from the mediator (M) to the dependent variable (Y) is denoted as $b$ and its standard error is $s e_{b}$. The formula, given multivariate normality for the standard error of the indirect effect or $a b$ is stated in Hayes (2013).

$$
\begin{gathered}
Z=\frac{a b}{s e_{a b}} \\
\text { Whereby } s e_{a b}=\sqrt{a^{2} s e_{b}^{2}+b^{2} s e_{a}^{2}+s e_{a}^{2} s e_{b}^{2}}
\end{gathered}
$$

If the z-value is greater than 1.96 , it means that the tested variable $\mathrm{M}$ is a mediator in the model and has mediating effect on the relationship between independent variable $\mathrm{X}$ and dependent variable $\mathrm{Y}$.

\section{Results}

The results of this study were done by a two-stage analytical procedure. Firstly, measurement model was done by a confirmatory factor analysis. And next, the structural model and Sobel test were examined.

\subsection{Measurement Model}

Crobach's Alpha is used to test the internal consistency of the indicators or each studied construct. As shown in table 2, Crobach's $\alpha$ values were calculated ranged from 0.718 to 0.878 which are above recommended value 0.70 (Hair, 2010). Therefore, all constructs were internally consistent and reliability.

In this study, all standardized factor loadings were ranged from 0.705 to 0.882 which are above the recommended value 0.70 according to Hair (2010). Convergent validity of the CFA results should be supported by composite 
reliability (CR) and average variance extracted (AVE). As presented result in Table 2, the CR and AVE value ranged from 0.720 to 0.878 and 0.563 to 0.674 , respectively, passing their recommended levels. Hair (2010) stated that the estimates of CR and AVE should be higher than 0.700 and 0.500 , respectively. Discriminant validity is established using the latent variable correlation matrix, which has the square root of AVE for the measures on the diagonal, and correlations among the measures as the off-diagonal elements (Table 3). Discriminant validity is determined by looking down the columns and across the rows and is deemed satisfactory if the diagonal elements are larger than off-diagonal elements (Fornell \& Larcker, 1981).

Table 2. Reliability and validity of the constructs

\begin{tabular}{llllll}
\hline Construct & Item & Cronbach's $\alpha$ & $\begin{array}{l}\text { Standardized Factor } \\
\text { Loading }\end{array}$ & $\begin{array}{l}\text { Composite Reliability } \\
\text { (CR) }\end{array}$ & $\begin{array}{l}\text { Average Variance } \\
\text { Extracted (AVE) }\end{array}$ \\
\hline Positive Factors (PF) & IS & 0.846 & $0.775^{* * *}$ & 0.853 & 0.593 \\
& RS & & $0.861^{* * *}$ & \\
& PD & & $0.727^{* * *}$ & & \\
& CS & & $0.705^{* * *}$ & & 0.563 \\
\hline Functional Value & PV1 & 0.718 & $0.766^{* * *}$ & 0.720 & 0.674 \\
(FV) & PV2 & & $0.731^{* * *}$ & \\
\hline Emotional Value & PV3 & 0.801 & $0.787^{* * *}$ & 0.805 & 0.643 \\
(EV) & PV4 & & $0.849^{* * *}$ & \\
\hline Customer Responses & CAT & 0.878 & $0.758^{* * *}$ & 0.878 & \\
(CR) & CD & & $0.742^{* * *}$ & & \\
& CI & & $0.882^{* * *}$ & & \\
& CAT & & $0.826^{* * *}$ & & \\
\hline
\end{tabular}

Note. $* * * p<0.001$.

Table 3. The latent variable correlation matrix: Discriminant validity

\begin{tabular}{lllll}
\hline & Positive Factors (PF) & Functional Value (FV) & Emotional Value (EV) & Customer Responses (CR) \\
\hline Positive Factors (PF) & $\mathbf{0 . 7 7 0}$ & & & \\
Functional Value (FV) & 0.549 & $\mathbf{0 . 7 5 0}$ & & \\
Emotional Value (EV) & 0.420 & 0.319 & $\mathbf{0 . 8 2 1}$ & $\mathbf{0 . 8 0 2}$ \\
Customer Responses (CR) & 0.507 & 0.531 & 0.397 & \\
\hline
\end{tabular}

Note. Square root of AVE is on the diagonal.

\subsection{Structural Equation Model}

The standardized path coefficienct indicated effect among the construst of the model are shown in figures as follow. The figure 2 shows the direct positive relationship between positive factor and customers' responses $\left(H_{1}\right.$ : $\beta 1=0.506, t=7.650, p<0.001)$ indicated that $\mathrm{H}_{1}$ was supported. It means the greater positive application of applying Big Data analytics, the better the customers's responses to their behavior. This results is consistent with previous study (Le \& Liaw, 2017).

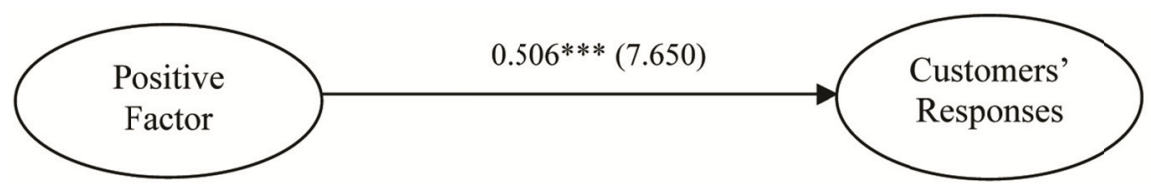

Figure 2. The results of direct effect

When adding the mediators (Figure 3), positive factor decreases its influence, but maintains a significant direct effect on customers' response $(c=0.239, t=3.084, p<0.01)$. The positve factor has strongly and positive significant effect to functional value $\left(a_{1}=0.554, t=7.519, p<0.001\right)$, then functional value has significant positive on customer's responses $\left(b_{1}=0.341, t=4.233, p<0.001\right)$. From the above result, we obtained the Sobel test which indicate $\mathrm{z}$-value, standard error (SE) and p-value. The result yields to customers' responses as follow: $\mathrm{z}$ $=3.993^{* * *}$. Therefore, $\mathrm{H}_{2}$ was supported, indicated that functional value acts as moderator in the relationship 
between positive factor of applying Big Data analytis and customers' responses. The finding corroborates the idea that customers receive high functional value after they has interaction with website using application of BDA and then improve much customers' responses.

Regarding the hypothesis $\mathrm{H}_{3}$, the positve factor has strongly and positive significant effect to emotional value $\left(a_{2}=\right.$ $0.426, t=6.399, p<0.001)$, then emotional value has significant positive on customer's responses $\left(b_{2}=0.197, t=\right.$ $3.088, p<0.001)$. Sobel test with result of $\mathrm{z}=3.131 * * *$ indicates that emotional value plays as mediating role of relationship between postive factor of applying BDA and customers' value.

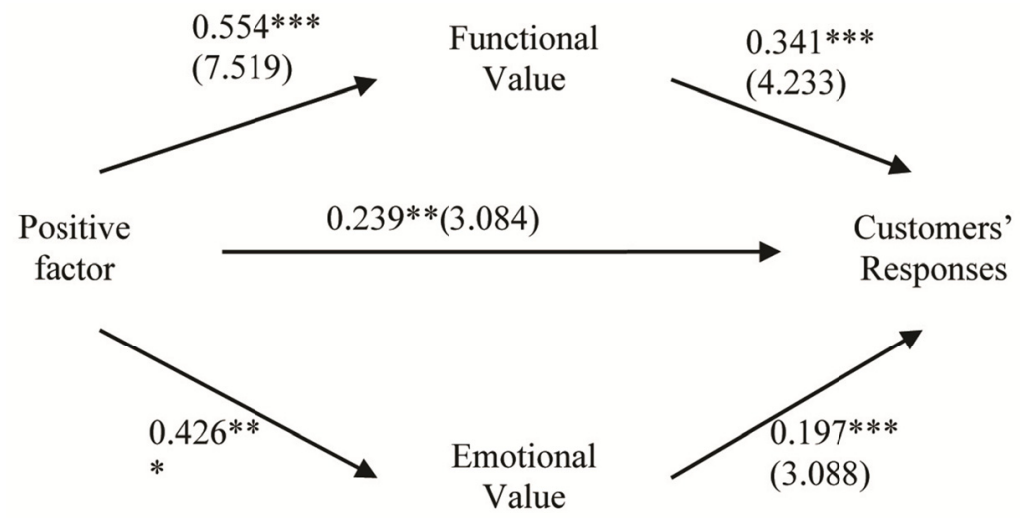

Figure 3. The results of mediation model

Note. $* * * p<0.001, * * p<0.01, * p<0.05$; value within the parenthesis is $t$-value.

Based on the results of direct and indirect effects, the indirect effect size is higher than direct effect, because indirect effect takes $53.31 \%$ of the total size in this multi mediation model, and the total effect of multiple mediation model is 0.51 . The direct effect decreased after adding mediators, but it is still account for $46.69 \%$ of total direct. It indicated that the positive factors of applying BDA had strong direct influence to customers' responses. However, the indirect effect is higher than indirect effect. It indicates that to gain the higher positive customers' response through customers' perceived value.

According to Hayes (2013), the comparison of indirect effects of two mediators is calculated by sobel z- Test as formulate:

$$
\mathrm{Z}=\frac{a 1 * b 1-a 2 * b 2}{\operatorname{Se}(a 1 * b 1-a 2 * b 2)}
$$

Whereas:

$$
\operatorname{Se}(a 1 * b 1-a 2 * b 2)=\sqrt{(a 1 * \operatorname{se}(b 1))^{2}+(b 1 * \operatorname{se}(a 1))^{2}+(a 2 * \operatorname{se}(b 2))^{2}+(b 2 * \operatorname{se}(a 2))^{2}}
$$

Table 4. Path comparison of indirect effects

\begin{tabular}{llllll}
\hline Path & Coefficient & Se & Coefficient & Se & Sobel - z \\
\hline $\mathrm{PF} \rightarrow \mathrm{FV} \rightarrow \mathrm{CR}$ & $0.554\left(\mathrm{a}_{1}\right)$ & $0.090\left(\mathrm{Sea}_{1}\right)$ & $0.341\left(\mathrm{~b}_{1}\right)$ & $0.065\left(\mathrm{Sea}_{2}\right)$ & $3.993^{* *}$ \\
$\mathrm{PF} \rightarrow \mathrm{EV} \rightarrow \mathrm{CR}$ & $0.426\left(\mathrm{a}_{2}\right)$ & $0.105\left(\mathrm{Sea}_{2}\right)$ & $0.197\left(\mathrm{~b}_{2}\right)$ & $0.040 \mathrm{Se}\left(\mathrm{b}_{2}\right)$ & $3.131^{* *}$ \\
Comparison z & & & & 1.93 \\
\hline $0.05, * * p<0.01, * * * p<0.001 . \mathrm{PF}=$ Positive Factor, FV $=$ Functional Value, EV $=$ Emotional Value, CR = Customers' Response.
\end{tabular}

The result $\mathrm{z}=1.93<1.96$ shows that there are no significant different mediating effect between two mediators, they are both important mediators, indicated that the hypothesis $\mathrm{H}_{4}$ was rejected. It means that customers take important view of functional value and emotional value. Therefore, customers receives functional value and emotional value after applying application of Big Data analytics application, after that they lead positive customers' responses. This result is similar results with previous study about customers' loyalty (Lim et al., 2006). 


\section{Conclusions}

Under the urgency of applying BDA in e-commerce, the purposes of this study are to evaluate the mediating role of two dimensions of perceived values on the relationship between positive factor of applying BDA and customers' responses. The first result found that the applying Big Data analytics brings the positive influences on customers' responses. Applications of applying DBA are such as information search, recommendation system, dynamic pricing and customer services. A recent study by Columbus (2014) stated about business value that injecting BDA may contribute $10 \%$ and more of the growth for $56 \%$ firms. For customers' value, applying BDA enables customers gain more confidence, feeling pleasure and having high satisfaction. Big Data analytics is new method for e-commerce firms to understand more about their customers. Therefore, e-vendors should adapt this new method to attract more customers' intention toward the positive applications of BDA.

Two dimensions of perceived value act the mediating role on the relationship between positive factor of applying BDA and customers' responses. This mediating effect is divided into a functional value (referring to economic valuations) effect and emotional value (relating feelings or internal emotions) effect. In the view of the results obtained, it is highlight that the customer perceived value is important key factor that is mediator to gain more positive customers' responses. There are no significant different mediating effect between functional value and emotional value. This finding highlights the notification that under BDA era in e-commerce, customers concern both important dimensions of perceived value. It can be explained that customers nowadays not only find their products or services but also seek enjoyment when online shopping. Therefore, it raises a question for e-vendors that how to use positive application of BDA effectively to gain more functional value and emotional value at the same time.

Big Data analytics has become the trend for intelligent marketing analytics for e-commerce landscape. Although the benefits of BDA are real and significant to business value and customer value, there remain some hidden potential challenges for e-vendors and customers also. The biggest challenges of Big Data are not provide clear direction to reach business target (Akter \& Wamba, 2016), find the right customers' information from massive data (Agarwal \& Dhar, 2014). BDA is process which works with Big Data, techniques, skills and systems to create competitive advances. Leading famous e-commerce firms have already injected and gained growth from BDA such as Google, Amazon, eBay, Taobao and others (Le \& Liaw, 2017).

\section{Future Research}

Future research of this study is mainly shown in two points. The first point is about the choice of sample, this study focused on potential customers as college students. They cannot represent the view of all online consumers such different occupational, age, experiences, so future research may include samples from diverse demographic population. The second point is beside positive factor of applying BDA to customers, it also bring negative factor and other risks. Therefore, the future research should deeply study about these factors to customers' responses.

\section{References}

Agarwal, R., \& Dhar, V. (2014). Editorial—Big data, data science, and analytics: The opportunity and challenge for IS research. INFORMS.

Akter, S., \& Wamba, S. F. (2016). Big data analytics in E-commerce: a systematic review and agenda for future research. Electronic Markets, 26(2), 173-194. https://doi.org/10.1007/s12525-016-0219-0

Aulia, S. A., Sukati, I., \& Sulaiman, Z. (2016). A review: Customer perceived value and its Dimension. Asian Journal of Social Sciences and Management Studies, 3(2), 150-162. https://doi.org/10.20448/journal.500/2016.3.2/500.2.150.162

Bridges, E., \& Florsheim, R. (2008). Hedonic and utilitarian shopping goals: The online experience. Journal of Business Research, 61(4), 309-314. https://doi.org/10.1016/j.jbusres.2007.06.017

Carlos, F. R. J., Sanchez, G. J., Angel, M. T. M., \& Llorens, M. J. (2006). Customer perceived value in banking services. International Journal of Bank Marketing, 24(5), 266-283. https://doi.org/10.1108/02652320610681729

Chen, S. C. (2012). The customer satisfaction-loyalty relation in an interactive e-service setting: The mediators. $\begin{array}{lllll}\text { Journal of Retailing and Consumer } & \text { Services, } 19(2),\end{array}$ https://doi.org/10.1016/j.jretconser.2012.01.001

Columbus, L. (2014). Making analytics accountable: $56 \%$ Of executives expect analytics to contribute To $10 \%$ Or more growth in 2014: Forbes. 
Cowles, D. L., Kiecker, P., \& Little, M. W. (2002). Using key informant insights as a foundation for e-retailing theory development. Journal of Business Research, 55(8), 629-636. https://doi.org/10.1016/S0148-2963(00)00203-4

Delone, W. H., \& McLean, E. R. (2003). The DeLone and McLean model of information systems success: a ten-year update. Journal of Management Information Systems, 19(4), 9-30. https://doi.org/10.1080/07421222.2003.11045748

Ehrenberg, A. S. (2000). Repetitive advertising and the consumer. Journal of Advertising Research, 40(6), 39-48. https://doi.org/10.2501/JAR-40-6-39-48

Fornell, C., \& Larcker, D. F. (1981). Evaluating structural equation models with unobservable variables and measurement error. Journal of Marketing Research, 39-50. https://doi.org/10.2307/3151312

Gefen, D. (2002). Customer loyalty in e-commerce. Journal of the Association for Information Systems, 3(1), 2.

Gharibi, S., Danesh, S., \& Shahrodi, K. (2012). Explain the effectiveness of advertising using the AIDA model. Interdisciplinary Journal of Contemporary Research in Business, 4(2), 926-940.

Hair, J. F. (2010). Multivariate data analysis. NJ, USA: Pearson College Division.

Haws, K. L., \& Bearden, W. O. (2006). Dynamic pricing and consumer fairness perceptions. Journal of Consumer Research, 33(3), 304-311. https://doi.org/10.1086/508435

Hayes, A. F. (2013). Introduction to mediation, moderation, and conditional process analysis: A regression-based approach. New York: Guilford Press.

Holbrook, M. B., \& Hirschman, E. C. (1982). The experiential aspects of consumption: Consumer fantasies, feelings, and fun. Journal of Consumer Research, 9(2), 132-140. https://doi.org/10.1086/208906

Huang, Z., Zeng, D., \& Chen, H. (2007). A comparative study of recommendation algorithms in e-commerce applications. IEEE Intelligent Systems, 22(5), 68-78.

Huber, F., Herrmann, A., \& Morgan, R. E. (2001). Gaining competitive advantage through customer value oriented management. Journal of Consumer Marketing, 18(1), 41-53. https://doi.org/10.1108/07363760110365796

Kotler, P., \& Armstrong, G. (2000). Principles of Marketing: Unit.

Kuo, Y. F., Wu, C. M., \& Deng, W. J. (2009). The relationships among service quality, perceived value, customer satisfaction, and post-purchase intention in mobile value-added services. Computers in Human Behavior, 25(4), 887-896. https://doi.org/10.1016/j.chb.2009.03.003

Le, T. M., \& Liaw, S. Y. (2017). Effects of Pros and Cons of Applying Big Data Analytics to Consumers' Responses in an E-Commerce Context. Sustainability, 9, 798. https://doi.org/10.3390/su9050798

Lee, T. R., Lin, J. H., Liao, L. W. C., \& Yeh, T. H. (2013). Managing the positive and negative characteristics of enterprise microblog to attract user to take action through the perspective of behavioural response. International Journal of Management and Enterprise Development, 12(4-6), 363-384. https://doi.org/10.1504/IJMED.2013.056443

Lim, H., Widdows, R., \& Park, J. (2006). M-loyalty: winning strategies for mobile carriers. Journal of Consumer Marketing, 23(4), 208-218. https://doi.org/10.1108/07363760610674338

Mackay, A. (2005). The practice of advertising. Sydney, Australia: Elsevier Butterworth, Fifth Edition.

McAfee, A., Brynjolfsson, E., Davenport, T. H., Patil, D., \& Barton, D. (2012). Big data. The management revolution. Harvard Bus Rev, 90(10), 61-67.

Overby, J. W., \& Lee, E.-J. (2006). The effects of utilitarian and hedonic online shopping value on consumer preference and intentions. Journal of Business Research, 59(10), 1160-1166. https://doi.org/10.1016/j.jbusres.2006.03.008

Preacher, K. J., \& Hayes, A. F. (2008). Asymptotic and resampling strategies for assessing and comparing indirect effects in multiple mediator models. Behavior Research Methods, 40(3), 879-891. https://doi.org/10.3758/BRM.40.3.879

Sanchez, J., Callarisa, L., Rodriguez, R. M., \& Moliner, M. A. (2006). Perceived value of the purchase of a tourism product. Tourism Management, 27(3), 394-409. https://doi.org/10.1016/j.tourman.2004.11.007 
Sweeney, J. C., \& Soutar, G. N. (2001). Consumer perceived value: The development of a multiple item scale. Journal of Retailing, 77(2), 203-220. https://doi.org/10.1016/S0022-4359(01)00041-0

Tang, M., \& Wu, Z. (2015). Research on the mechanisms of big data on consumer behavior using the models of $\mathrm{C} 2 \mathrm{C}$ e-commerce and countermeasures. African Journal of Business Management, 9(1), 18. https://doi.org/10.5897/AJBM2014.7560

Teo, T. S. (2001). Demographic and motivation variables associated with Internet usage activities. Internet Research, 11(2), 125-137. https://doi.org/10.1108/10662240110695089

Zeithaml, V. A. (1988). Consumer perceptions of price, quality, and value: a means-end model and synthesis of evidence. The Journal of Marketing, 2-22. https://doi.org/10.2307/1251446

\section{Copyrights}

Copyright for this article is retained by the author, with first publication rights granted to the journal.

This is an open-access article distributed under the terms and conditions of the Creative Commons Attribution license (http://creativecommons.org/licenses/by/4.0/). 